\title{
Insecticidal Action of Several Isolates of Entomopathogenic Fungi against The Granary Weevil Sitophilus granarius
}

\author{
Spiridon Mantzoukas ${ }^{1,2, *}$, Ioannis Lagogiannis ${ }^{1,2}$, Maria Mpekiri ${ }^{2}$, Ioannis Pettas ${ }^{3}$ and \\ Panagiotis A. Eliopoulos 4 (D) \\ 1 Department of Pharmacy, University of Patras, 26504 Patras, Greece; lagoipp@gmail.com \\ 2 ELGO-Demeter, Plant Protection Division of Patras, 26442 Patras, Greece; mpekirimairh@gmail.com \\ 3 Department of Chemistry, University of Ioannina, 45100 Ioannina, Greece; pettasgian@gmail.com \\ 4 Department of Agriculture \& Agrotechnology, University of Thessaly, 41110 Larissa, Greece; \\ eliopoulos@uth.gr \\ * Correspondence: mantzoukas@upatras.gr
}

Received: 4 September 2019; Accepted: 11 October 2019; Published: 13 October 2019

\begin{abstract}
The insecticidal virulence of various entomopathogenic fungal isolates retrieved from soil samples was tested on adults of the granary weevil Sitophilus granarius (L.) (Coleoptera: Curculionidae). Bioassays were carried out in the laboratory where experimental adults were sprayed with $1 \mathrm{~mL}$ of conidial suspension $\left(10^{8}\right.$ conidia/mL) from each isolate. Mortality was recorded at 7, 14, and 21 days after exposure. Mean mortality, mean lethal time, survival, and hazard effect were estimated for each isolate. Two isolates of Beauveria bassiana (Balsamo) Vuillemin (Hypocreales: Cordycipitaceae), one isolate of Aspergillus insuetus (Bainier) Thom \& Church (Eurotiales: Trichocomaceae) and Metarhizium anisopliae (Metschinkoff) Sorokin (Hypocreales: Clavicipitaceae) resulted in the highest mortality (97-100\%). The isolates with both the highest hazard effect and the lowest survival rate were Aspergillus sp. and M. anisopliae. Our results indicate that entomopathogenic fungi have the potential to become a very useful tool in reducing chemical applications in storage facilities.
\end{abstract}

Keywords: entomopathogenic fungi; virulence; Sitophilus granarius L.; Curculionidae; biological control; IPM

\section{Introduction}

Insects are major agricultural post-harvest pests causing serious damage to the quality, the quantity, and the commercial and agronomic value of various stored products [1]. Nowadays, stored product pest control is based mainly on the use of two broad categories of insecticides: residual insecticides and fumigants. Chemical strategies involve direct application of contact insecticides to grain and surface treatments on bag stacks, storage structures providing protection from invading pests, and fumigants used to control pests that are already infesting stored grain [2,3]. However, the development of insect resistance to many chemical insecticides, environmental pollution issues, human safety problems and the demands of consumers for residue-free products have led researchers to search for alternative non-chemical control means that do not leave residues on the product and are generally safe for the environment and human health $[4,5]$.

Sitophilus granarius (L.) (Coleoptera: Curculionidae) belongs to the most severe storage pests of raw cereals in the world and its control consists mainly in the application of fumigants and residual insecticides [6]. The long-term use of these synthetic chemicals holds the risk that inadequate treatments could lead to resistance in pest populations, a fact that has already been reported for 
Sitophilus species [7]. Resistance development coupled with public demand for residue-free food propels the exploration of alternative biological control methods.

Insect pathogens including entomopathogenic fungi, bacteria, viruses, protozoa, and nematodes offer many advantages such as high efficacy and compatibility with other IPM methods, and they are thus considered to be among the most promising alternatives to chemical-based insect control [8-12]. There is a plethora of studies available in literature focusing on the use of pathogens, mostly fungi, against stored product pests [13-19].

Entomopathogenic Fungi (EF) are naturally occurring microorganisms which are environmentally safe and have low mammalian toxicity $[19,20]$. Furthermore, they have the potential to develop on cadavers, thus reintroducing more inoculum into the system. Hence, while long term residual persistence is considered a drawback in the case of conventional insecticides, it is a desirable characteristic of EF [13].

The most commonly studied EF species against stored product pests is Beauveria bassiana (Balsamo) Vuillemin (Hypocreales: Cordycipitaceae). Several laboratory and field studies have demonstrated its efficient insecticidal action against postharvest insects [11,17,21-26]. Unlike B. bassiana, there are disproportionably fewer data on the use of other common EF species such as Metarhizium anisopliae (Metschinkoff), Sorokin (Hypocreales: Clavicipitaceae), and Isaria fumosorosea (Wize) (Hypocreales: Clavicipitaceae), despite the fact that there is strong evidence that they can be successfully used for the protection of stored grains against several insect pests [11,27-30].

Mycopesticides have been proven to have considerable potential for the management of insects while minimizing the adverse effects of insecticides, and they have accordingly been used worldwide to control various pests [31-34]. Although several stored product insects suffer high mortality as a result of pathogenic disease, the practical use of fungal pathogens as biological control agents in storage facilities has received very little attention $[5,9]$.

As part of our project on the development and application of $\mathrm{EF}$ in the integrated pest management (IPM) of stored product pests, we investigated the potential of 27 fungal isolates (including B. bassiana, M. anisopliae, I. fumosorosea, and other entomopathogenic fungi) as biological control agents against the granary weevil S. granarius, a notorious pest of stored grain with worldwide distribution [6]. The granary weevil is a primary pest of grain since it is capable of infesting undamaged kernels [6]. Apart from grain (mainly wheat and maize) it can also attack other cereal products such as spaghetti. Very serious quantitative and qualitative losses may be caused including severe reduction in the weight and quality of grain as a result of the larvae feeding on the endosperm, secondary infestations by molds, bacteria and other insects, product contamination with frass, insect body fragments, and heating of the grain due to insects' action (hot spots) [1]. The fungal isolates were recovered from soil samples from Greece and Cyprus. The main purpose of our study is to enhance the application of safe biological means in stored product IPM.

\section{Materials and Methods}

\subsection{Rearing of the Weevils}

The population of S. granarius was originally collected from infested wheat in Achaia (W. Greece) and reared for more than a year in the Plant Protection Institute of Patras, Achaia, Greece. Insects were maintained in glass jars ( 0.251 capacity, Amiglass Athens Greece) containing $200 \mathrm{~g}$ of pesticide-free sterilized hard wheat (Triticum durum Desf. var. Mexa). The jars were covered with a sterilized muslin cloth and the adults were sieved out after two weeks. Insects were kept in a growth chamber (PHC Europe/Sanyo/Panasonic Biomedical MLR-352-PE), in controlled environmental conditions $\left(25 \pm 1^{\circ} \mathrm{C}\right.$, $65 \pm 5 \%$ relative humidity, complete darkness). 


\subsection{Soil Samples}

Soil samples were randomly collected from Glafkos $\left(38^{\circ} 12^{\prime} 23.50^{\prime \prime} \mathrm{N}, 21^{\circ} 47^{\prime} 2.25^{\prime \prime}\right.$ E), Ayia $\left(38^{\circ} 15^{\prime} 43.98^{\prime \prime} \mathrm{N}, 21^{\circ} 44^{\prime} 58.31^{\prime \prime} \mathrm{E}\right)$, Kastritsi ( $\left.38^{\circ} 17^{\prime} 13.08^{\prime \prime} \mathrm{N}, 21^{\circ} 48^{\prime} 12.46^{\prime \prime} \mathrm{E}\right)$, and Zavlani ( $38^{\circ} 15^{\prime} 22.38^{\prime \prime} \mathrm{N}$, $21^{\circ} 45^{\prime} 25.95^{\prime \prime}$ E) in the prefecture of Achaia, Greece, and insect baits were used for the retrieval of fungal isolates (Table 1). The locations of the samplings were recorded with a GPS Garmin Etrex device. Once the surface litter was removed, a soil core borer was used to dig into a depth of $10 \mathrm{~cm}$ to extract the soil samples. These were then placed in plastic bags and kept at $4{ }^{\circ} \mathrm{C}$ until they were transferred to the laboratory stalls where they were placed on a rough cardboard for $24 \mathrm{~h}$ to reduce their humidity. This step was deemed essential as in conditions of excess humidity, the entomopathogenic nematodes of the soil attack the larvae of insect baits before the entomopathogenic fungi. Once it was drier, the soil was sieved and placed in Petri dishes where ten bait larvae or adults per species were also inserted. Each soil sample was tested three times; thirty individuals per species were consequently tested per soil sample. The samples were then left in special dark chambers at $25 \pm 1{ }^{\circ} \mathrm{C}$ for 14 days.

Table 1. Isolates of various entomopathogenic fungal species which were tested in the present study. Coleopteran and Lepidopteran insect species were used as baits to retrieve the fungi. Fungal DNA sequences were matched with the Basic Local Alignment Search Tool (Blast ID Number).

\begin{tabular}{|c|c|c|c|c|}
\hline Fungal Species & Isolate & Bait & Collection Site & Blast ID Number \\
\hline $\begin{array}{l}\text { Apophysomyces } \\
\text { ossiformis }\end{array}$ & B8B & Rhyzopertha dominica & Zavlani-W.Greece & 20140422CS9P1_A03_2016-04-27 \\
\hline Aspergillus sp. & G11 & Tribolium confusum & Patra-W.Greece & 20140422CS4P1_D01_2016-04-27 \\
\hline A. insuetus & D17 & Tribolium confusum & Zavlani-W.Greece & 20140422CS5P1_E01_2016-04-27 \\
\hline \multirow{10}{*}{ B. bassiana } & $\mathrm{H} 20$ & Rhyzopertha dominica & Glafkos-W.Greece & 20170105CS5P4_E01_2017-01-11 \\
\hline & $\mathrm{D}$ & Tribolium confusum & Patra-W.Greece & 20170105CS5P1_E01_2017-01-11 \\
\hline & $10 \mathrm{~T}$ & Tribolium confusum & Glafkos-W.Greece & 20170105CS6P2_F02_2017-01-11 \\
\hline & BD14 & Tenebrio molitor & Glafkos-W.Greece & 20170105CS6P3_G02_2017-01-11 \\
\hline & ST $28 / 11$ & Endophytic pepper plant & Patra-W.Greece & 20140422CS6P5_H02_2016-04-27 \\
\hline & E20 & Endophytic strawberry plants & Patra-W.Greece & 20140422CS6P6_H02_2016-04-27 \\
\hline & B18 & Endophytic potato plant & Patra-W.Greece & 20140422CS6P9_H02_2016-04-27 \\
\hline & $\mathrm{BB}^{\mathrm{a}}$ & Galleria mellonella & Athens-C. Greece & 20140422CS6P8_H02_2016-04-27 \\
\hline & $\mathrm{B} 5 / 12^{\mathrm{a}}$ & Galleria mellonella & Athens-C. Greece & 20140422CS6P10_H02_2016-04-27 \\
\hline & ST19 & Sesamia nonagioides & Patra-W.Greece & 20140422CS6P11_H02_2016-04-27 \\
\hline \multirow{2}{*}{ Chaetomium sp. } & BD12 & Rhyzopertha dominica & Patra-W.Greece & 20140422CS8P2_H02_2016-04-27 \\
\hline & BD2 & Rhyzopertha dominica & Zavlani-W.Greece & 20140422CS8P3_H02_2016-04-27 \\
\hline C. acropullum & $2 \mathrm{R}$ & Rhyzopertha dominica & Patra-W.Greece & 20140422CS4P2_D02_2016-04-27 \\
\hline C. iranianum & $\mathrm{B} 17 / 3$ & Tribolium confusum & Patra-W.Greece & 20140422CS8P1_H01_2016-04-27 \\
\hline C. truncatulum & B4 & Tribolium confusum & Zavlani-W.Greece & 20170105CS7P1_G01_2017-01-11 \\
\hline I. fumosorosea & $\mathrm{I}^{\mathrm{a}}$ & Galleria melonella & Ag. Stefanos-C. Greece & 20170105CS10P1_G01_2017-01-11 \\
\hline \multirow{4}{*}{ M. anisopliae } & Met A & Rhyzopertha dominica & Zavlani-W.Greece & 20140422CS3P2_C02_2016-04-27 \\
\hline & Met B & Plodia interpunctella & Glafkos-W.Greece & 20140422CS3P3_C02_2016-04-27 \\
\hline & $\mathrm{B}^{8} \mathrm{~A}^{\mathrm{a}}$ & Galleria mellonella & Paramali-Cyprus & 20140422CS3P4_C02_2016-04-27 \\
\hline & $\mathrm{TH}^{\mathrm{a}}$ & Galleria mellonella & Paramali-Cyprus & 20140422CS3P7_C02_2016-04-27 \\
\hline P. lilacinum & B42 & Plodia interpunctella & Kastritsi-W.Greece & 20140422CS3P4_C02_2016-04-27 \\
\hline T. gamsii & $1 \mathrm{R}, 4 \mathrm{R}, \mathrm{Z}$ & Rhyzopertha dominica & Zavlani-W.Greece & 20140422CS7P1_G01_2016-04-27 \\
\hline
\end{tabular}

\subsection{Isolation of Entomopathogenic Fungi}

All infected larvae/adults were contained in Petri dishes on the nutrient Sabouraud Dextrose Agar (SDA) material. Alternatively, fungal conidia from the infected larvae/adults were cultivated on the same material. The Petri dishes were kept in a dark space, at $25 \pm 1{ }^{\circ} \mathrm{C}$ and $65 \pm 5 \%$ relative humidity, to enable the incubation of the fungi. The developed fungi were isolated again to avoid infestation and to achieve clear cultivation. 


\subsection{Lab Culture of Fungal Isolates}

The fungal isolates that were tested during the present study are presented in Table 1 . To prepare the appropriate suspensions, the isolates were grown in $9 \mathrm{~cm} \varnothing$ Petri dishes containing SDA and were left in the dark for 15 days at $25 \pm 1{ }^{\circ} \mathrm{C}$ and $65 \pm 5 \%$ relative humidity. The Petri dishes were sealed with Parafilm ${ }^{\circledR}$ American National Can, Chigago, USA) to avoid contamination. For each dose of the bioassays, fresh conidia were collected from the cultures after 15 days. Conidial suspensions were prepared by "scraping" the surface of the Petri dish using a sterile loop and transferring the conidia into a $500 \mathrm{~mL}$ glass beaker containing $50 \mathrm{~mL}$ of sterile distilled water plus $0.05 \%$ Tergitol ${ }^{\circledR} \mathrm{NP9}$ (Sigma-Aldrich, St. Louis, USA). The conidial suspension was panned across several layers of a sterile cloth and prepared by mixing the solution with a magnetic stirrer for $5 \mathrm{~min}$ [35]. The concentration of fungal conidia in the conidial suspension was determined using a Neubauer hemocytometer (WEBER SCIENTIFIC hemocytometer for cell counting) (Weber Scientific Inc., Hamilton Township, USA). Dilutions were prepared by adding $10 \mathrm{~mL}$ of the conidial suspensions to the desired quantity of sterile water, providing the final concentration of $10^{8}$ conidia per $\mathrm{ml}$ for all fungal isolates. The specific concentration was chosen given that it is a very common dose that has been widely used in a plethora of relevant studies. Conidial viability was $>97 \%$ for all fungal isolates.

\subsection{Bioassay}

Adult weevils (1-2 weeks old) were used for experimentation. The evaluation of the virulence of each fungal isolate was carried out in Petri dishes with 10 adult beetles and $10 \mathrm{~g}$ of sterilized undamaged wheat kernels. Fifty adults were tested in each treatment (10 adults per replication for 5 replications per treatment). Adults of $\mathrm{S}$. granarius were sprayed directly with $2.5 \mathrm{~mL}$ of conidial suspension containing $10^{8}$ conidia/mL of fungus, using a Potter spray tower (Burkard Manufacturing Co. Ltd., Rickmansworth, Hertfordshire, UK) at $1 \mathrm{kgf} \mathrm{cm}^{-2}$. Untreated adults were used as control. All the insects were maintained under controlled conditions $\left(25^{\circ} \mathrm{C}, 65 \pm 5 \%\right.$ relative humidity, complete darkness), as described above. Petri dishes (control and treated adults) were checked after 7, 14 and 21 days and dead adults were counted and collected. 2.6. Pathogen Identification Methods

All dead weevils were immediately submerged in $95 \%$ ethanol for $1 \mathrm{~min}$, washed in sterile distilled water for $5 \mathrm{~min}$, allowed to dry, and then placed on moistened filter paper. The above-mentioned process was completed inside a laminar flow chamber (Equip Vertical Air Laminar Flow Cabinet Clean Bench, Mechanical Application LTD, Athens, Greece). Cadavers were kept at $25^{\circ} \mathrm{C}$ and $65 \pm 5 \%$ relative humidity, for 5-7 days in the dark, and those that showed hyphal growth characteristic of EF were recorded as infected. Dead Sitophilus adults were removed from the Petri dishes and superficial disinfestation with $\mathrm{NaOCl}_{2}$ was applied to avoid fungal saprophytic growth. The sterilized dead adults were then kept individually in Petri dishes on a damp filter paper until mycelia appeared. Sitophilus cadavers showing external mycelia growth were examined using a microscope ZEISS Primo Star (Carl Zeiss Microscopy GmbH, Jena, Germany) at a 400x magnification, and fungi were determined based on the shape and size of hyphal growth [36-39].

The DNA sequencing process was also applied, adopting the method outlined by Rogers and Bendich [40]. The conidia were scraped off the surface of the dead S. granarius by using a sterile loop and transferring the conidia to PD Agar (In House technic). The genomic DNA (gDNA) was extracted applying universal primer sets ITS4 (5'-TCCTCCGCTTATTGATATGC-3') and ITS5 (5'-GGAAGTAAAAGTCGTAAC AAGG-3'), a fragment of the ITS spacer region was expanded. PCR reactions $(30 \mu \mathrm{L})$ included $50 \mathrm{ng}$ of template gDNA, $1.25 \mu \mathrm{L}$ of each $10 \mathrm{pM}$ oligonucleotide, $1 \mu \mathrm{L}$ of $10 \mathrm{mM}$ dNTPs, $1 \mu \mathrm{L}$ of $2 \mathrm{U} / \mu \mathrm{L}$ Taq DNA polymerase (Minotech), $1.5 \mu \mathrm{L}$ of $\mathrm{MgCl}_{2}, 2.5 \mu \mathrm{L}$ of $10 \times \mathrm{PCR}$ buffer. The PCR protocol for amplification of ITS regions includes 31 cycles at $94{ }^{\circ} \mathrm{C}$ for $60 \mathrm{~s}$, at $55^{\circ} \mathrm{C}$ for $60 \mathrm{~s}$, and at $72{ }^{\circ} \mathrm{C}$ for $90 \mathrm{~s}$, followed by a final elongation at $72{ }^{\circ} \mathrm{C}$ for $5 \mathrm{~min}$. PCR products were kept at $4{ }^{\circ} \mathrm{C}$. The quantity and quality of PCR products were resolved by gel electrophoresis using $2 \%$ agarose gel, which was stained with SYBR Safe DNA Gel Stain (Invitrogen) and visualized under UV 
light (BIO RAD, Molecular Imager Gel Doc XR System). The amplified products were purified and sequenced in CeMIA SA, University of Thessaly.

\subsection{Statistical Analysis}

In all cases, control mortality was very low $(<2 \%)$ and, therefore, no correction was considered necessary for the mortality data. All values were arcsine transformed prior to analysis. Data were analyzed by two-way ANOVA using the general linear model of the SPSS 23.0 Windows (IBM Corp. 2015, New York, USA). In case of significant $F$ values, means were compared using the Bonferroni test. The Probit analysis method was also selected to determine the median lethal time of $S$. granarius following the application of the pathogen concentrations. The Cox Regression method [41] was selected to determine the hazard effect of the isolates over S. granarius. It is a survival analysis regression model which describes the relation between the event incidence, as expressed by the hazard function, and a set of covariates. Comparison of survival distributions was obtained using Breslow (Generalized Wilcoxon) [42]. Comparison of Median lethal Time was performed using one-way ANOVA (Treatment as Factor).

Survival data are generally described and modeled in terms of two related probabilities, survival and hazard. The survival probability (which is also called "the survivor function"), $\mathrm{S}(\mathrm{t})$, is the probability that an individual survives from the time origin (e.g., beginning of treatment) to a specified future time, $\mathrm{t}$.

The hazard probability is usually denoted by $h(t)$ or $\lambda(t)$ and refers to the probability that an individual who is under observation at a time $t$, has an event at that time. It represents the instantaneous event rate for an individual who has already survived by time $t$. Thus, while the survivor function reflects the cumulative non-occurrence of an event, the hazard function focuses on the occurrence of that event.

The mathematical expression of the Cox model is:

$$
h(t)=h 0(t) \times \exp \{b 1 \times 1+b 2 \times 2+\cdots+b p x p\}
$$

where the hazard function $\mathrm{h}(\mathrm{t})$ is dependent on (or determined by) a set of $\mathrm{p}$ covariates $(\mathrm{x} 1, \mathrm{x} 2, \ldots, \mathrm{xp})$, whose impact is measured by the size of the respective coefficients $(b 1, b 2, \ldots, b p)$. The term $h 0$ is called the baseline hazard and is the value of the hazard if all the xi are equal to zero (the quantity $\exp (0)$ equals 1$)$. The ' $t$ ' in $h(t)$ reminds us that the hazard may (and probably will) vary over time.

\section{Results}

A total of 27 isolates were morphologically identified as they were retrieved from dead cadavers. The fungus which appeared on the cadavers of the 27 isolates was also confirmed by PCR. Fungal DNA sequences in the present work were matched with the Basic Local Alignment Search Tool (NCBI BLAST) (Table 1). Mycelial and conidial growth on cadavers suggested that recorded mortality was pathogen related. Observations of cadavers showed that external mycelium appears within the first $72 \mathrm{~h}$ after placing them on moist filter paper.

Mean mortality (\%) of S. granarius is presented in Table 2, indicating high efficacy for many isolates by day 21 of the experiment. The several fungal isolates affected the survival time of the insect in diverse ways. All main effects and associated interactions between exposure time and fungal isolates, were significant for the mortality levels of $S$. granarius adults. (Table 3 ).

Two isolates of B. bassiana (H20 and 10T), Aspergillus insuetus (Bainier) Thom \& Church (Eurotiales: Trichocomaceae) (D17) and M. anisopliae (Met A) caused the highest mortality, whereas Chaetomium iranianum Asgari and Zare (Sordariomycetes: Chaetomiaceae) (B17/3) as well as M. anisopliae (B8A) recorded the highest pest survival. As expected, the highest virulence to $S$. granarius was recorded after 21 days, while control mortality was lower than $2 \%$ even after the maximum exposure interval. 
Table 2. Mean mortality $( \pm \mathrm{SD})$ and Median Lethal Time of $S$. granarius adults exposed to various entomopathogenic fungal isolates. Means of the same column followed by the same letter are not significantly different (Bonferroni test, $p=0.05$ ). Median Lethal Time was estimated by the Probit analysis and Means of the same column followed by the same letter are not significantly different (Bonferroni test, $p=0.05$ ).

\begin{tabular}{|c|c|c|c|c|c|}
\hline \multirow{2}{*}{ Fungal Species } & \multirow{2}{*}{ Isolate } & \multicolumn{3}{|c|}{ Mean Mortality (\%) } & \multirow{2}{*}{$\begin{array}{c}\text { Median Lethal Time } \\
\text { (days) }(\mathrm{F}=5.230, \mathrm{df}=27 \\
p<0.001\end{array}$} \\
\hline & & 7 days & 14 days & 21 days & \\
\hline $\begin{array}{c}\text { Apophysomyces } \\
\text { ossiformis }\end{array}$ & B8B & $0.0 \pm 0.0 \mathrm{k}$ & $3.3 \pm 0.5 \mathrm{j}$ & $20.0 \pm 1.7 \mathrm{k}$ & $20.4 \pm 0.2 \mathrm{a}$ \\
\hline Aspergillus sp. & G11 & $6.6 \pm 0.5 \mathrm{i}$ & $20.0 \pm 2.0 \mathrm{e}$ & $26.7 \pm 2.0 \mathrm{j}$ & $19.1 \pm 0.8 \mathrm{a}$ \\
\hline A. insuetus & D17 & $100.0 \pm 0.0 \mathrm{a}$ & $100.0 \pm 0.0 \mathrm{a}$ & $100.0 \pm 0.0 \mathrm{a}$ & $7.2 \pm 0.2 \mathrm{e}$ \\
\hline \multirow{10}{*}{ B. bassiana } & BD14 & $10.0 \pm 1.0 \mathrm{~h}$ & $16.6 \pm 2.1 \mathrm{e}$ & $16.6 \pm 2.11$ & $19.1 \pm 0.8 a$ \\
\hline & $\mathrm{D}$ & $50.0 \pm 2.0 \mathrm{~d}$ & $70.0 \pm 2.0 c$ & $76.6 \pm 2.5 c$ & $12.6 \pm 0.4 \mathrm{c}$ \\
\hline & E20 & $0.0 \pm 0.0 \mathrm{k}$ & $6.6 \pm 1.1 \mathrm{~h}$ & $36.6 \pm 5.5 \mathrm{~g}$ & $19.8 \pm 0.3 a$ \\
\hline & $\mathrm{H} 20$ & $60.0 \pm 2.6 c$ & $100.0 \pm 0.0 \mathrm{a}$ & $100.0 \pm 0.0 \mathrm{a}$ & $9.8 \pm 0.6 c$ \\
\hline & ST19 & $20.0 \pm 1.0 f$ & $23.3 \pm 1.5 \mathrm{e}$ & $26.7 \pm 1.1 \mathrm{j}$ & $17.9 \pm 0.1 b$ \\
\hline & ST $28 / 11$ & $13.3 \pm 1.5 \mathrm{~g}$ & $13.3 \pm 1.5 f$ & $16.7 \pm 1.51$ & $19.1 \pm 0.8 \mathrm{a}$ \\
\hline & $10 \mathrm{~T}$ & $66.7 \pm 3.2 \mathrm{c}$ & $86.6 \pm 2.3 b$ & $96.0 \pm 0.5 b$ & $10.5 \pm 0.9 c$ \\
\hline & B18 & $23.3 \pm 1.5 f$ & $40.0 \pm 3.0 \mathrm{~d}$ & $53.3 \pm 2.1 f$ & $16.5 \pm 1.1 b$ \\
\hline & B5/12 & $0.0 \pm 0.0 \mathrm{k}$ & $3.3 \pm 0.5 j$ & $16.6 \pm 0.51$ & $20.3 \pm 0.2 \mathrm{a}$ \\
\hline & BB & $40.0 \pm 2.6 \mathrm{e}$ & $46.6 \pm 3.2 \mathrm{~d}$ & $60.0 \pm 4.4 \mathrm{~d}$ & $14.9 \pm 0.3 b$ \\
\hline C. acropullum & $2 \mathrm{R}$ & $10.0 \pm 1.0 \mathrm{~h}$ & $13.3 \pm 1.5 \mathrm{f}$ & $16.6 \pm 1.11$ & $19.3 \pm 0.9 \mathrm{a}$ \\
\hline C. iranianum & $\mathrm{B} 17 / 3$ & $0.0 \pm 0.0 \mathrm{k}$ & $6.6 \pm 0.5 \mathrm{i}$ & $6.6 \pm 0.5 \mathrm{~m}$ & $20.5 \pm 0.3 a$ \\
\hline C. truncatulum & B4 & $6.6 \pm 0.5 \mathrm{i}$ & $10.0 \pm 0.0 \mathrm{~g}$ & $30.0 \pm 1.7 \mathrm{j}$ & $19.8 \pm 0.7 \mathrm{a}$ \\
\hline \multirow{2}{*}{ Chaetomium sp. } & BD2 & $0.0 \pm 0.0 \mathrm{k}$ & $6.6 \pm 1.4 \mathrm{i}$ & $13.3 \pm 2.31$ & $20.4 \pm 0.2 \mathrm{a}$ \\
\hline & BD12 & $10.0 \pm 1.0 \mathrm{~h}$ & $10.0 \pm 1.0 \mathrm{~g}$ & $44.0 \pm 3.0 \mathrm{~h}$ & $19.6 \pm 0.8 \mathrm{a}$ \\
\hline I. fumosorosea & I & $20.0 \pm 1.7 f$ & $36.6 \pm 3.2 \mathrm{~d}$ & $50.0 \pm 4.4 \mathrm{f}$ & $17.1 \pm 0.8 b$ \\
\hline \multirow{4}{*}{ M. anisopliae } & Met A & $80.0 \pm 2.6 b$ & $100 \pm 0.0 \mathrm{a}$ & $100 \pm 0.0 \mathrm{a}$ & $8.4 \pm 0.5 \mathrm{~d}$ \\
\hline & Met B & $53.3 \pm 3.0 \mathrm{~d}$ & $66.6 \pm 4.2 \mathrm{c}$ & $70.0 \pm 3.6 c$ & $12.6 \pm 1.2 \mathrm{c}$ \\
\hline & B8A & $0.0 \pm 0.0 \mathrm{k}$ & $3.3 \pm 0.5 j$ & $10.0 \pm 1.0 \mathrm{~m}$ & $20.4 \pm 0.3 a$ \\
\hline & $\mathrm{TH}$ & $6.6 \pm 1.1 \mathrm{i}$ & $20.0 \pm 1.7 \mathrm{e}$ & $27.0 \pm 1.5 \mathrm{j}$ & $19.1 \pm 0.8 \mathrm{a}$ \\
\hline P. lilacinum & B42 & $3.3 \pm 0.5 j$ & $3.3 \pm 0.5 \mathrm{j}$ & $16.6 \pm 1.51$ & $20.1 \pm 0.5 a$ \\
\hline \multirow{3}{*}{ T. gamsii } & $\mathrm{Z}$ & $40.0 \pm 3.4 \mathrm{e}$ & $60.0 \pm 4.6 c$ & $80.0 \pm 3.4 \mathrm{c}$ & $11.4 \pm 1.0 \mathrm{c}$ \\
\hline & $1 \mathrm{R}$ & $50.0 \pm 2.5 \mathrm{~d}$ & $60.0 \pm 3.5 c$ & $63.3 \pm 3.2 d$ & $13.3 \pm 1.2 \mathrm{c}$ \\
\hline & $4 \mathrm{R}$ & $0.0 \pm 0.0 \mathrm{k}$ & $0.0 \pm 0.0 \mathrm{k}$ & $13.3 \pm 2.31$ & $20.4 \pm 0.1 \mathrm{a}$ \\
\hline Control & $\mathrm{C}$ & $0.0 \pm 0.0 \mathrm{k}$ & $0.0 \pm 0.0 \mathrm{k}$ & $1.0 \pm 0.0 \mathrm{n}$ & $20.9 \pm 0.0 f$ \\
\hline
\end{tabular}

Table 3. ANOVA parameters for main effects and associated interactions between exposure time and fungal isolates for mortality levels of S. granarius adults (error df 167).

\begin{tabular}{cccc}
\hline Source & df & $\mathbf{F}$ & $p$ \\
\hline Exposure time & 2 & 30.844 & $<0.05$ \\
Fungal isolates & 27 & 5.323 & $<0.05$ \\
$\begin{array}{c}\text { Exposure time } \times \text { Fungal } \\
\text { isolates }\end{array}$ & 54 & 4.435 & $<0.05$ \\
\hline
\end{tabular}

Accordingly, in relation to the lowest median lethal time, this was estimated at $7.2 \pm 0.2$ days for $A$. insuetus (D17), $8.4 \pm 0.5$ days for $M$. anisopliae (Met A), $9.8 \pm 0.6$ days for B. bassiana (H20), $10.5 \pm 0.9$ days for B. bassiana (10T), $11.4 \pm 1.0$ days for Trichoderma gamsii (Z) Samuels \& Druzhin (Hypocreales: Hypocreaceae), $12.6 \pm 1.2$ days for M. anisopliae (Met B) and B. bassiana (D), and $13.3 \pm 1.2$ days for T. gamsii (1R). In all other isolates, the median lethal time exceeded 15 days (Table 5). 
Table 4. Survival and hazard effect of entomopathogenic fungi on S. granarius adults (Cox Regression method)(-2 Log Likelihood: 3998.475) (Chi-square: 414.314, $\mathrm{df}=27, p<0.001) *$ Survival effect: the probability that an individual survives from the time origin (e.g., beginning of treatment) to a specified future time; ${ }^{* *}$ Hazard effect: the probability that an individual who is under observation at a time $t$, has an event at that time; ${ }^{* * *}$ Index values could not be estimated due to complete mortality.

\begin{tabular}{|c|c|c|c|c|}
\hline \multirow{2}{*}{ Fungal Species } & \multirow{2}{*}{ Isolate } & \multirow{2}{*}{ Exposure Time (Days) } & \multicolumn{2}{|c|}{ Survival Table } \\
\hline & & & Survival Effect * & Hazard Effect ** \\
\hline \multirow{3}{*}{ Apophysomyces ossiformis } & \multirow{3}{*}{ B8B } & 7 & $* * *$ & $* * *$ \\
\hline & & 14 & 0.967 & 0.034 \\
\hline & & 21 & 0.800 & 0.223 \\
\hline \multirow{3}{*}{ Aspergillus sp. } & \multirow{3}{*}{ G11 } & 7 & 0.933 & 0.069 \\
\hline & & 14 & 0.800 & 0.223 \\
\hline & & 21 & 0.733 & 0.310 \\
\hline \multirow{3}{*}{ A. insuetus } & \multirow{3}{*}{ D17 } & 7 & 0.000 & 3.401 \\
\hline & & 14 & $* * *-$ & $* * *-$ \\
\hline & & 21 & $* * *-$ & $* * *-$ \\
\hline \multirow{30}{*}{ B. bassiana } & \multirow{3}{*}{ BD14 } & 7 & 0.900 & 0.105 \\
\hline & & 14 & 0.833 & 0.182 \\
\hline & & 21 & $* * *$ & $* * *-$ \\
\hline & \multirow{3}{*}{$\mathrm{D}$} & 7 & 0.500 & 0.693 \\
\hline & & 14 & 0.300 & 1.204 \\
\hline & & 21 & 0.233 & 1.455 \\
\hline & \multirow{3}{*}{ E20 } & 7 & $* * *-$ & $* * *$ \\
\hline & & 14 & 0.933 & 0.069 \\
\hline & & 21 & 0.633 & 0.457 \\
\hline & \multirow{3}{*}{$\mathrm{H} 20$} & 7 & 0.400 & 0.916 \\
\hline & & 14 & $* * *-$ & $* * *-$ \\
\hline & & 21 & $* * *-$ & $* * *$ \\
\hline & \multirow{3}{*}{ ST19 } & 7 & 0.800 & 0.223 \\
\hline & & 14 & 0.767 & 0.266 \\
\hline & & 21 & 0.733 & 0.310 \\
\hline & \multirow{3}{*}{ ST $28 / 11$} & 7 & 0.867 & 0.143 \\
\hline & & 14 & $* * *-$ & $* * *$ \\
\hline & & 21 & 0.833 & 0.182 \\
\hline & & 7 & 0.333 & 1.099 \\
\hline & $10 \mathrm{~T}$ & 14 & 0.133 & 2.015 \\
\hline & & 21 & 0.033 & 3.401 \\
\hline & & 7 & 0.767 & 0.266 \\
\hline & B18 & 14 & 0.600 & 0.511 \\
\hline & & 21 & 0.467 & 0.762 \\
\hline & & 7 & $* * *$ & $* * *$ \\
\hline & $\mathrm{B} 5 / 12$ & 14 & 0.967 & 0.034 \\
\hline & & 21 & 0.833 & 0.182 \\
\hline & & 7 & 0.600 & 0.511 \\
\hline & $\mathrm{BB}$ & 14 & 0.533 & 0.629 \\
\hline & & 21 & 0.400 & 0.916 \\
\hline & & 7 & 0.900 & 0.105 \\
\hline C. acropullum & $2 \mathrm{R}$ & 14 & 0.867 & 0.143 \\
\hline & & 21 & 0.833 & 0.182 \\
\hline & & 7 & $* * *$ & $* * *$ \\
\hline C. iranianum & $\mathrm{B} 17 / 3$ & 14 & 0.933 & 0.069 \\
\hline & & 21 & $* * *-$ & $* * *$ \\
\hline & & 7 & 0.933 & 0.069 \\
\hline C. truncatulum & B4 & 14 & 0.900 & 0.105 \\
\hline & & 21 & 0.700 & 0.357 \\
\hline & & 7 & 0.900 & 0.105 \\
\hline & BD12 & 14 & $* * *$ & $* * *-$ \\
\hline Chaetomium sp & & 21 & 0.567 & 0.568 \\
\hline Chaеtomium sp & & 7 & $* * *$ & $* * *$ \\
\hline & BD2 & 14 & 0.967 & 0.034 \\
\hline & & 21 & 0.898 & 0.108 \\
\hline & & 7 & 0.800 & 0.223 \\
\hline I. fumosorosea & I & 14 & 0.633 & 0.457 \\
\hline & & 21 & 0.500 & 0.693 \\
\hline
\end{tabular}


Table 5. Survival and hazard effect of entomopathogenic fungi on S. granarius adults (Cox Regression method)(-2 Log Likelihood: 3998.475) (Chi-square: 414.314, df $=27, p<0.001) *$ Survival effect: the probability that an individual survives from the time origin (e.g., beginning of treatment) to a specified future time; ${ }^{* *}$ Hazard effect: the probability that an individual who is under observation at a time $t$, has an event at that time; ${ }^{* * *}$ Index values could not be estimated due to complete mortality.

\begin{tabular}{|c|c|c|c|c|}
\hline \multirow{2}{*}{ Fungal Species } & \multirow{2}{*}{ Isolate } & \multirow{2}{*}{ Exposure Time (Days) } & \multicolumn{2}{|c|}{ Survival Table } \\
\hline & & & Survival Effect * & Hazard Effect $* *$ \\
\hline \multirow{12}{*}{ M. anisopliae } & \multirow{3}{*}{ Met A } & 7 & 0.200 & 1.609 \\
\hline & & 14 & $* * *_{-}$ & $* * *$ \\
\hline & & 21 & $* * *-$ & $* * *-$ \\
\hline & \multirow{3}{*}{ Met B } & 7 & 0.467 & 0.762 \\
\hline & & 14 & 0.333 & 1.099 \\
\hline & & 21 & 0.300 & 1.204 \\
\hline & \multirow{3}{*}{ B8A } & 7 & $* * *$ & $* * *-$ \\
\hline & & 14 & 0.967 & 0.034 \\
\hline & & 21 & 0.900 & 0.105 \\
\hline & \multirow{3}{*}{$\mathrm{TH}$} & 7 & 0.933 & 0.069 \\
\hline & & 14 & 0.800 & 0.223 \\
\hline & & 21 & 0.733 & 0.310 \\
\hline \multirow{3}{*}{ P. lilacinum } & \multirow{3}{*}{ B42 } & 7 & 0.967 & 0.034 \\
\hline & & 14 & $* * *_{-}$ & $* * *_{-}$ \\
\hline & & 21 & 0.833 & 0.182 \\
\hline \multirow{9}{*}{ T. gamsii } & \multirow{4}{*}{$\mathrm{Z}$} & 7 & 0.433 & 0.836 \\
\hline & & 14 & 0.200 & 1.609 \\
\hline & & 21 & 0.033 & 3.401 \\
\hline & & 7 & 0.500 & 0.693 \\
\hline & \multirow[t]{2}{*}{$1 \mathrm{R}$} & 14 & 0.400 & 0.916 \\
\hline & & 21 & 0.367 & 1.003 \\
\hline & \multirow{3}{*}{$4 \mathrm{R}$} & 7 & $* * *_{-}$ & $* * *_{-}$ \\
\hline & & 14 & $* * *_{-}$ & $* * *_{-}$ \\
\hline & & 21 & 0.867 & 0.143 \\
\hline
\end{tabular}

The survival effect of $S$. granarius adults was dependent on the hazard effect of the used isolate and the exposure time (Table 5). The highest hazard rate was recorded for the isolates of B. bassiana (H20), A. insuetus (D17) and M. anisopliae (Met A) at 7 days after exposure. The highest hazard rate was also recorded for B. bassiana (10T) but at 21 days after exposure. In contrast, the highest survival effect was recorded for the isolates B. bassiana (ST 28/11), C. acropullum (2R), Chaetomium sp (BD2), M. anisopliae (TH) and T. gamsii (4R) at 21 days after the exposure (Table 5).

\section{Discussion}

Entomopathogenic fungi are being developed worldwide for the control of insect pests and some products are already available commercially $[43,44]$. There is increasing evidence that habitat selection drives the pathogenicity of EF species [45]. Thus, results from our study indicate that screening of potential isolates should not be limited to those isolated from the original host.

Sitophilus granarius is one of the less studied storage pests as far as myco-biological control is concerned. Shams et al. [23] recorded $60 \%$ mortality of S. granarius after 13 days, when weevils were immersed in a conidial solution of B. bassiana. They also estimated $\mathrm{LT}_{50}$ at 10.45 days via probit analysis. When $S$. granarius adults were exposed to grain sprayed with a B. bassiana conidial suspension, the results demonstrated very low mortality (3\%) [46].

Moreover, the insecticidal efficacy of EF is highly influenced by several other factors such as the insect's behavior, population density, age, nutrition and genetic information, environmental conditions, as well as the effect of host physiology and morphology on its sensitivity to biological control agents such as EF [47]. Therefore, the differences in insect susceptibility to EF could not be explained solely as a function of the applied conidial concentration [48].

Although significant variability in virulence was detected among various EF isolates, $B$. bassiana (H20 and 10T), A. insuetus (D17) and M. anisopliae (Met A) were generally the most virulent against S. granarius, with $10 \mathrm{~T}$ causing significantly lower mortality ( $96 \%)$ than the other three mentioned isolates 
$(100 \%)$. These isolates caused the highest mortality within 7 days after inoculation, thus combining virulence and speed of action, which are the basic requirements for adequate effectiveness. The isolates with both the highest hazard effect and the lowest survival effect were B. bassiana (H20 and 10T), A. insuetus (D17) and M. anisopliae (Met A). The highest hazard effect indicates increased virulence or toxicity of the fungus over S. granarius adults, which conversely translates into the lowest survival effect of the fungus for the insect.

This is the first time that A. insuetus, Apophysomyces ossiformis P.C. Misra (Mucorales: Saksenaeaceae), Purpureocillium lilacinum (Thom) Luangsaard, Hou-braken, Hywel-Jones and Samson (Hypocreales: Ophiocordycipitaceae), C. iranianum, Chaetomium truncatulum Asgari and Zare, and Chaetomium acropullum X. Wei Wang (Sordariales: Chaetomiaceae) have been tested as potential biological control agents against an insect pest. Moreover, our study is the first attempt to test the EF species $T$. gamsii against a storage pest.

In general, eight $\mathrm{EF}$ isolates produced noteworthy mortality $(>70 \%)$, whereas 11 isolates caused very low weevil mortality $(<30 \%)$. There are a plethora of older and recent reviews reporting on EF treatments against stored product pests, with varying and often contradictory results. Cherry et al. [14] have also demonstrated that different isolates of M. anisopliae and B. bassiana can provide good control of Callosobruchus maculatus (F.) (Coleoptera: Bruchidae) by immersion bioassay at 12 days, whereby B. bassiana was reported to be more virulent than M. anisopliae. Khashaveh et al. [49] claimed that $B$. bassiana can be successfully used against stored wheat pests. Similarly, Wakefield et al. [50] reported that some B. bassiana isolates can achieve $100 \%$ mortality of Oryzaephilus surinamensis (L.) (Coleoptera: Silvanidae) (organophosphate resistant strain) after 10 days of treatment with a dose of $1 \times 10^{8}$ conidia/mL. In older studies, mortality of stored grain pests reached $80-100 \%$ after $10-20$ days $[8,51]$.

Kassa [52] also reported that B. bassiana isolates were virulent against Sitophilus zeamais L. (Coleoptera: Curculionidae), but only at doses higher than $10^{7}$ conidia/mL and as such, variability among the different B. bassiana isolates was apparent. Hidalgo et al. [53] also pointed out that it is possible to achieve a useful level of control of $S$. zeamais by using formulated B. bassiana conidia. In laboratory experiments, Rodrigues and Pratissoli [54] evaluated the pathogenicity of Beauveria brongniartii (Saccardo) Petch (Deuteromycotina, Hyphomycetes) and M. anisopliae isolates against S. zeamais and Acanthoscelides obtectus Say (Coleoptera: Chrysomelidae). The first EF species caused $89 \%$ mortality to S. zeamais and $47 \%$ to A. obtectus, while M. anisopliae caused less than $50 \%$ mortality to both insects.

Batta [28] recorded high mortality of Rhyzopertha dominica F. (Coleoptera: Bostrichidae) after 7 days of treatment with $M$. anisopliae. Greater mortality of stored grain pests was achieved when these were inoculated with Beauveria rather than Metarhizium isolates [55,56]. In contrast, Dal Bello et al. [57] reported that treatment of $S$. oryzae with M. anisopliae was not effective.

In our experiment, median lethal time values indicate that the examined isolates are as effective as any other isolate reported in literature. Similar median lethal time values have been reported for various storage pests treated with EF species $[17,23,49,55,58,59]$. However, it should be mentioned that variation, not only in experimentation methods, fungal isolates and insect strains but also in median lethal time estimation methods, renders the direct comparison of these values impossible.

\section{Conclusions}

In summary, our results demonstrate that $\mathrm{EF}$ show promise against stored product pests and should therefore be further investigated as potential biological control agents and as a valuable component of stored product IPM. Considering the propensity of Sitophilus species to develop resistance to synthetic chemicals, the exploration of alternative biological control methods appears even more necessary. Although this is only a preliminary investigation into the use of EF, the fungal isolates we tested showed encouraging insecticidal effects which, however, need to be extensively followed-up. Future research steps include establishing the biosafety of these fungi for non-target organisms, examining 
performance assurance in challenging environments, and the creation of formulations of enhanced persistence, longer shelf life, ease of application, and pathogen virulence.

Author Contributions: Conceptualization, S.M.; methodology, S.M. and P.A.E.; software, S.M.; validation, S.M., I.L., M.M. and I.P.; formal analysis, S.M.; investigation, S.M. and P.A.E.; resources, S.M. and P.A.E.; data curation, S.M.; writing — original draft preparation, S.M.; writing—review and editing, S.M. and P.A.E.; visualization, S.M.; supervision, N/A; project administration, N/A; funding acquisition, N/A.

Funding: This research received no external funding.

Acknowledgments: We would like to thank Ioanna Zampara, MA in Interpreting and Translating, for her help with the language. Many thanks to three anonymous reviewers for their suggestions.

Conflicts of Interest: The authors declare no conflict of interest.

\section{References}

1. Nayak, M.K.; Daglish, G.J. Importance of stored product insects. In Recent Advances in Stored Product Protection; Athanassiou, C., Arthur, F., Eds.; Springer: Berlin/Heidelberg, Germany, 2018. [CrossRef]

2. Zettler, J.L.; Arthur, F.H. Chemical control of stored product insects with fumigants and residual treatments. Crop Prot. 2000, 19, 8-10. [CrossRef]

3. Arthur, F.H.; Subramanyam, B. Chemical control in stored products. In Stored Product Protection; Hagstrum, D.W., Phillips, T.W., Cuperus, G.W., Eds.; Kansas State University: Manhattan, KS, USA, 2012; pp. 95-100.

4. Subramanyam, B.; Hagstrum, D.W. Integrated Management of Insects in Stored Products; Marcel Dekker: New York, NY, USA, 1996.

5. Subramanyam, B.; Hagstrum, D.W. Alternatives to Pesticides in Stored-Product IPM; Kluwer Academic Publishers: Boston, MA, USA, 2000.

6. Longstaff, B.C. Biology of the grain pest species of the genus Sitophilus (Coleoptera: Curculionidae): A critical review. Protect. Ecol. 1981, 2, 83-130.

7. Benhalima, H.; Chaudhry, M.Q.; Mills, K.A.; Price, N.R. Phosphine resistance in stored-product insects collected from various grain storage facilities in Morocco. J. Stored Prod. Res. 2004, 40, 241-249. [CrossRef]

8. Rice, W.C.; Cogburn, R.R. Activity of the entomopathogenic fungus Beauveria bassiana (Deuteromycota: Hyphomycetes) against three coleopteran pests of stored-grain. J. Econ. Entomol. 1999, 92, 691-694. [CrossRef]

9. Schöller, M.E.; Flinn, P.W.; Grieshop, M.J.; Zd'árková, E. Biological control of stored product pests. In Insect Management for Food Storage and Processing, 2nd ed.; Heaps, J.W., Ed.; AACC International: Eagan, MN, USA, 2006; pp. 67-87.

10. Weinzierl, R.; Higgins, R. Insect Pest Management for Stored Grain. In Illinois Agricultural Pest Management Handbook: Serving Agriculture and the Environment; Cooperative Extension Service College of Agriculture, University of Illinois at Urbana-Champaign: Champaign, IL, USA, 2008; Available online: http://hdl.handle. net/2142/89687 (accessed on 8 March 2019).

11. Shafighi, Y.; Ziaee, M.; Ghosta, Y. Diatomaceous earth used against insect pests, applied alone or in combination with Metarhizium anisopliae and Beauveria bassiana. J. Plant Prot. Res. 2014, 54, 62-66. [CrossRef]

12. Arora, R. Microbial control in insect pest management: Achievements and challenges. In Biological and Molecular Approaches in Pest Management; Singh, B., Arora, R., Gosal, S.S., Eds.; Scientific Publishers: Jodhpur, India, 2015; pp. 97-152.

13. Moore, D.; Lord, J.C.; Smith, S.M. Pathogens. In Alternatives to Pesticides in Stored-Product IPM; Subramanyam, B., Hagstrum, D.W., Eds.; Springer Science \& Business Media: New York, NY, USA, 2000.

14. Cherry, A.J.; Abalo, P.; Hell, K. A laboratory assessment of the potential of different strains of the entomopathogenic fungi Beauveria bassiana (Balsamo) Vuillemin and Metarhizium anisopliae (Metschnikoff) to control Callosobruchus maculatus (F.) (Coleoptera: Bruchidae) in stored cowpea. J. Stored Prod. Res. 2005, 41, 295-309. [CrossRef]

15. Wakil, W.; Ghazanfar, M.U. Entomopathogenic fungus as a biological control agent against Rhyzopertha dominica f. (coleoptera: Bostrychidae) on stored wheat. Arch. Phytopathol. Pflanzenschutz 2010, 43, 1236-1242. [CrossRef] 
16. Riasat, T.; Wakil, W.; Ashfaq, M.; Sahi, S.T. Effect of Beauveria bassiana mixed with diatomaceous earth on mortality, mycosis and sporulation of Rhyzopertha dominica on stored wheat. Phytoparasitica 2011, 39, 325-331. [CrossRef]

17. Abdel-Raheemm, M.; Ismail, I.; Abdel-Rahman, R.; Farag, N.; Abdel-Rhman, I. Entomopathogenic fungi, Beauveria bassiana (Bals.) and Metarhizium anisopliae (Metsch.) as biological control agents on some stored product insects. J. Entomol. Zool. Stud. 2015, 3, 316-320.

18. Batta, Y.A. Recent advances in formulation and application of entomopathogenic fungi for biocontrol of stored-grain insects. Biocontrol Sci. Technol. 2016, 26, 1-28. [CrossRef]

19. Batta, Y.A.; Kavallieratos, N.G. The use of entomopathogenic fungi for the control of stored-grain insects. Int. J. Pest Manag. 2018, 64, 77-87. [CrossRef]

20. Cox, P.D.; Wilkin, D.R. The potential use of biological control of pests of stored grain. In Home-Grown Cereals Authority Research Review 36; HGCA: London, UK, 1996; p. 53.

21. Lord, J.C. Low humidity, moderate temperature, and desiccant dust favor efficacy of Beauveria bassiana (Hyphomycetes: Moniliales) for the lesser grain borer, Rhyzopertha dominica (Coleoptera: Bruchidae). Biol. Control 2005, 34, 180-186. [CrossRef]

22. Lord, J.C. Enhanced efficacy of Beauveria bassiana for red flour beetle with reduced moisture. J. Econ. Entomol. 2007, 100, 1071-1074. [CrossRef] [PubMed]

23. Shams, G.; Safaralizadeh, M.H.; Imani, S.; Shojai, M.; Aramideh, S. A laboratory assessment of the potential of the entomopathogenic fungi Beauveria bassiana (Beauvarin) to control Callosobruchus maculatus (F.) (Coleoptera: Bruchidae) and Sitophilus granarius (L.) (Coleoptera: Curculionidae). Afr. J. Microbiol. Res. 2011, 5, 1192-1196.

24. Wakil, W.; Riasat, T.; Ghazanfar, M.U.; Kwon, Y.J.; Shaheen, F.A. Aptness of Beauveria bassiana and enhanced diatomaceous earth (DEBBM) for control of Rhyzopertha dominica F. Entomol. Res. 2011, 41, 233-241. [CrossRef]

25. Wakil, W.; Riasat, T.; Ashfaq, M. Residual efficacy of thiamethoxam, Beauveria bassiana (Balsamo) Vuillemin, and diatomaceous earth formulation against Rhyzopertha dominica F. (Coleoptera: Bostrychidae). J. Pest Sci. 2012, 85, 341-350. [CrossRef]

26. Storm, C.; Scoates, F.; Nunn, A.; Potin, O.; Dillon, A. Improving efficacy of Beauveria bassiana against stored grain beetles with a synergistic co-formulant. Insects 2016, 7, 42. [CrossRef]

27. Batta, Y.A. Control of rice weevil (Sitophilus oryzae L., Coleoptera: Curculionidae) with various formulations of Metarhizium anisopliae. Crop Prot. 2004, 23, 103-108. [CrossRef]

28. Batta, Y.A. Control of the lesser grain borer (Rhyzopertha dominica (F.), Coleoptera: Bostrichidae) by treatments with residual formulations of Metarhizium anisopliae (Metschnikoff) Sorokin (Deuteromycotina: Hyphomycetes). J. Stored Prod. Res. 2005, 41, 221-229. [CrossRef]

29. Sabbour, M.M.; Abd-el-aziz, S.E.; Sherief, M.A. Efficacy of Three Entomopathogenic Fungi Alone or in Combination with Diatomaceous Earth Modifications for the Control of Three Pyralid Moths in Stored Grains. J. Plant Prot. Res. 2012, 52, 359-363. [CrossRef]

30. Riasat, T.; Wakil, W.; Yasin, M.; Kwon, Y.J. Mixing of Isaria fumosorosea with enhanced diatomaceous earth and bitterbarkomycin for control of Rhyzopertha dominica. Entomol. Res. 2013, 43, 215-223. [CrossRef]

31. Butt, T.M.; Tariq, M.; Jackson, C.; Magan, N. Fungi as Biocontrol Agents: Progress, Problems and Potential; CABI: New York, NY, USA, 2001. [CrossRef]

32. Hunter, D.M. Mycopesticides as part of integrated pest management of locusts and grasshoppers. J. Orthoptera Res. 2005, 14, 197-201. [CrossRef]

33. Chandler, D.; Bailey, A.S.; Mark Tatchell, G.; Davidson, G.; Greaves, J.; Grant, W.P. The development, regulation and use of biopesticides for integrated pest management. Proc. R. Soc. B Biol. Sci. 2011, 366, 1987-1998. [CrossRef] [PubMed]

34. Manivel, S.B.; Rajkumar, G.S. Mycopesticides: Fungal Based Pesticides for Sustainable Agriculture. In Fungi and Their Role in Sustainable Development: Current Perspectives; Springer: Singapore, 2018; pp. 183-203. [CrossRef]

35. Quesada-Moraga, E.; Navas-Cortés, J.A.; Maranhao, E.A.A.; Ortiz-Urquiza, A.; Santiago-Álvarez, C. Factors affecting the occurrence and distribution of entomopathogenic fungi in natural and cultivated soils. Mycol. Res. 2007, 111, 947-966. [CrossRef]

36. Mugani, L.; Bridge, P.D.; Evans, H.C. A chemotaxonomic evaluation of the genus Beauveria. Mycol. Res. 1989, 92, 199-209. [CrossRef] 
37. Varela, A.; Morales, E. Characterization of some Beauveria bassiana isolates and their virulence toward the coffee berry borer Hypothenemus hampei. J. Invertebr. Pathol. 1996, 67, 147-152. [CrossRef]

38. Gams, W.; Bissett, J. Morphology and identification of Trichoderma. In Trichoderma and Gliocladium, Basic Biology, Taxonomy and Genetics; Kubicek, C.P., Harman, G.E., Eds.; Taylor and Francis Ltd.: London, UK, 1998.

39. Brunner-Mendoza, C.; Reyes-Montes, M.; Moonjely, S.; Bidochka, M.J.; Toriello, C. A review on the genus Metarhizium as an entomopathogenic microbial biocontrol agent with emphasis on its use and utility in Mexico. Biocontrol Sci. Technol. 2019, 29, 83-102. [CrossRef]

40. Rogers, S.O.; Bendich, A.J. Extraction of DNA from milligram amounts of fresh, herbarium and mummified plant tissues. Plant Mol. Biol. 1985, 5, 69-76. [CrossRef]

41. Cox, D.R. Regression Models and Life-Tables. J. R. Stat. Soc. Ser. B (Methodol.) 1972, 34, 187-202. [CrossRef]

42. IBM Corp. IBM SPSS Statistics for Windows; IBM Corp.: Armonk, NY, USA, 2015; Available online: http://www-01.ibm.com/support/docview.wss?uid=swg21476197 (accessed on 8 March 2019).

43. Miller, D.W. Commercial Development of Entomopathogenic Fungi: Formulation and Delivery. In Abstracts of Papers of the American Chemical Society; American Chemical Society: Washington, DC, USA, 1995; pp. 213-220.

44. Maina, U.M.; Galadima, I.B.; Gambo, F.M.; Zakaria, D. A review on the use of entomopathogenic fungi in the management of insect pests of field crops. J. Entomol. Zool. Stud. 2018, 6, 27-32.

45. Bidochka, M.J.; Kamp, A.M.; De Croos, J.N.A. Insect Pathogenic Fungi: From Genes to Populations. In Fungal Pathology; Springer: Heidelberg, The Netherlands, 2000. [CrossRef]

46. Hluchý, M.; Samšiňáková, A. Comparative study on the susceptibility of adult Sitophilus granarius (L.) (Coleoptera: Curculionidae) and larval Galleria mellonella (L.) (Lepidoptera: Pyralidae) to the entomogenous fungus Beauveria bassiana (Bals.) Vuill. J. Stored Prod. Res. 1989, 25, 61-64. [CrossRef]

47. Fargues, J.; Goettel, M.S.; Smits, N.; Ouedraogo, A.; Vidal, C.; Lacey, L.A.; Lomer, C.J.; Rougier, M. Variability in susceptibility to simulated sunlight of conidia among isolates of entomopathogenic Hyphomycetes. Mycopathologia 1996, 135, 171-181. [CrossRef] [PubMed]

48. Cox, P.D.; Wakefield, M.E.; Price, N.; Wildey, K.B.; Chambers, J.; Moore, D.; Aquino De Muro, M.; Bell, B.A. The potential use of insect-specific fungi to control grain storage pests in empty grain stores. HGCA Proj. Rep. 2004, 341, 1-49.

49. Khashaveh, A.; Safaralizadeh, M.H.; Ghosta, Y. Pathogenicity of Iranian isolates of Metarhizium anisopliae (Metschinkoff) (Ascomycota: Hypocreales) against Trogoderma granarium Everts (Coleoptera: Dermestidae). Biharean. Biol. 2011, 5, 51-55.

50. Wakefield, M.E.; Cox, P.D.; Moore, D.; De Muro, M.A.; Bell, B.A. Mycopest: Results and perspectives. In Proceedings of the VI meeting of COST Action, Working Group IV, Biocontrol of Arthropod Pests in Stored Products, Locorotondo, Italy, 23-29 June 2005; Volume 842, pp. 17-27.

51. Padin, S.B.; Dal Bello, G.M.; Vasicek, A.L. Pathogenicity of Beauveria bassiana for adults of Tribolium castaneum (Col.: Tenebrionidae) in stored grains. Entomophaga 1997, 42, 569-574. [CrossRef]

52. Kassa, A. Development and Testing of Mycoinsecticides Based on Submerged Spores and Aerial Conidia of the Entomopathogenic Fungi Beauveria bassiana and Metarhizium anisopliae (Deuteromycotina: Hyphomycetes) for Control of Locusts, Grasshoppers and Storage Pests. Ph.D. Thesis, Georg-August Universität, Göttingen, Germany, 2003. Available online: https:/cuvillier.de/de/shop/publications/3139 (accessed on 25 February 2019).

53. Hidalgo, E.; Moore, D.; Le Patourel, G. The effect of different formulations of Beauveria bassiana on Sitophilus zeamais in stored maize. J. Stored Prod. Res. 1998, 34, 171-179. [CrossRef]

54. Rodrigues, C.; Pratissoli, D. Pathogenicity of Beauveria brongniartii (Sacc.) Petch and Metarhizium anisopliae (Mots.) Sorok and their effect on the corn weevil and the bean beetle. An. Soc. Entomol. Bras. 1990, 19, 301-306.

55. Moino, A.; Alves, S.B.; Pereira, R.M. Efficacy of Beauveria bassiana (Balsamo) Vuillemin isolates for control of stored-grain pests. J. Appl. Entomol. 1998, 122, 301-305. [CrossRef]

56. Dal Bello, G.; Padín, S.; Juárez, P.; Pedrini, N.; De Giusto, M. Biocontrol of Acanthoscelides obtectus and Sitophilus oryzae with diatomaceous earth and Beauveria bassiana on stored grains. Biocontrol Sci. Technol. 2006, 16, 215-220. [CrossRef]

57. Dal Bello, G.; Padin, S.; López Lastra, C.; Fabrizio, M. Laboratory evaluation of chemical-biological control of the rice weevil (Sitophilus oryzae L.) in stored grains. J. Stored Prod. Res. 2000, 37, 77-84. [CrossRef] 
58. Mahdneshin, Z.; Vojoudi, S.; Ghosta, Y.; Safaralizadae, M.H.; Saber, M. Laboratory evaluation of the entomopathogenic fungi, Iranian isolates of Beauveria Bassiana (balsamo) Vuillemin and Metarhizium anisopliae (metsch) Sorokin against the control of the cowpea weevil, callosobruchus maculatus f. (Coleoptera: Bruchidae). Afr. J. Microbiol. Res. 2011, 5, 5215-5220. [CrossRef]

59. Sewify, G.H.; El Shabrawy, H.A.; Eweis, M.E.; Naroz, M.H. Efficacy of Entomopathogenic Fungi, Beauveria Bassiana and Metarhizium Anisopliae for Controlling Certain Stored Product Insects. Egypt. J. Biol. Pest Control 2014, 24, 191-196. article distributed under the terms and conditions of the Creative Commons Attribution (CC BY) license (http://creativecommons.org/licenses/by/4.0/). 